\title{
Maximal COX-2 and ppRb expression in neurons occurs during early Braak stages prior to the maximal activation of astrocytes and microglia in Alzheimer's disease Jeroen JM Hoozemans*1,5, Elise S van Haastert ${ }^{1}$, Robert Veerhuis ${ }^{3,4}$, Thomas Arendt ${ }^{4}$, Wiep Scheper ${ }^{2}$, Piet Eikelenboom ${ }^{3}$ and Annemieke JM Rozemuller ${ }^{1}$
}

Address: ${ }^{1}$ Department of Neuropathology, Academic Medical Center, P.O. Box 22700, 1100 DE Amsterdam, The Netherlands, ${ }^{2}$ Neurogenetics Laboratory, Academic Medical Center, University of Amsterdam, Amsterdam, The Netherlands, ${ }^{3}$ Department of Psychiatry, VU University medical center, Amsterdam, The Netherlands, ${ }^{4}$ Department of Clinical Chemistry and Alzheimer Center, VU University medical center, Amsterdam, The Netherlands and ${ }^{5}$ Department of Neuroanatomy, Paul Flechsig Institute for Brain Research, University of Leipzig, Leipzig, Germany

Email: Jeroen JM Hoozemans* - j.j.hoozemans@amc.uva.nl; Elise S van Haastert - e.s.vanhaaster@amc.uva.nl;

Robert Veerhuis - r.veerhuis@vumc.nl; Thomas Arendt - Thomas.Arendt@medizin.uni-leipzig.de; Wiep Scheper - w.scheper@amc.uva.nl; Piet Eikelenboom - piete@ggzba.nl; Annemieke JM Rozemuller - j.m.rozemuller@amc.uva.nl

* Corresponding author

Published: 2I November 2005

Journal of Neuroinflammation 2005, 2:27 doi:10.1186/1742-2094-2-27
Received: 24 October 2005

Accepted: 21 November 2005

This article is available from: http://www.jneuroinflammation.com/content/2/1/27

(C) 2005 Hoozemans et al; licensee BioMed Central Ltd.

This is an Open Access article distributed under the terms of the Creative Commons Attribution License (http://creativecommons.org/licenses/by/2.0), which permits unrestricted use, distribution, and reproduction in any medium, provided the original work is properly cited.

\begin{abstract}
Neuronal expression of cyclooxygenase-2 (COX-2) and cell cycle proteins is suggested to contribute to neurodegeneration during Alzheimer's disease (AD). The stimulus that induces COX-2 and cell cycle protein expression in $A D$ is still elusive. Activated glia cells are shown to secrete substances that can induce expression of COX-2 and cell cycle proteins in vitro. Using post mortem brain tissue we have investigated whether activation of microglia and astrocytes in AD brain can be correlated with the expression of COX-2 and phosphorylated retinoblastoma protein $(\mathrm{ppRb})$. The highest levels of neuronal COX-2 and ppRb immunoreactivity are observed in the first stages of AD pathology (Braak 0-II, Braak A). No significant difference in COX-2 or ppRb neuronal immunoreactivity is observed between Braak stage 0 and later Braak stages for neurofibrillary changes or amyloid plaques. The mean number of COX-2 or ppRb immunoreactive neurons is significantly decreased in Braak stage C compared to Braak stage A for amyloid deposits. Immunoreactivity for glial markers KPI, CR3/43 and GFAP appears in the later Braak stages and is significantly increased in Braak stage V-VI compared to Braak stage 0 for neurofibrillary changes. In addition, a significant negative correlation is observed between the presence of KPI, CR3/43 and GFAP immunoreactivity and the presence of neuronal immunoreactivity for COX-2 and PPRb. These data show that maximal COX-2 and ppRb immunoreactivity in neurons occurs during early Braak stages prior to the maximal activation of astrocytes and microglia. In contrast to in vitro studies, post mortem data do not support a causal relation between the activation of microglia and astrocytes and the expression of neuronal COX-2 and ppRb in the pathological cascade of AD.
\end{abstract}




\section{Findings}

Aberrant expression of cyclins, cyclin dependent kinases (CDKs) and their inhibitors has been observed in post mitotic neurons in Alzheimer's disease (AD) $[1,2]$. Proteins that normally function to control cell cycle progression in actively dividing cells may play a role in the death of post mitotic neurons in $\mathrm{AD}$ [3]. The retinoblastoma protein $(\mathrm{pRb})$ regulates cell proliferation by controlling progression through the restriction point within the G1phase of the cell cycle [4]. pRb sequesters members of the E2F gene family of transcription factors. Cell cycledependent phosphorylation of $\mathrm{pRb}$ by CDKs inactivates $\mathrm{pRb}$ and inhibits $\mathrm{pRb}$ target binding, allowing cell cycle progression. The expression of phosphorylated $\mathrm{pRb}$ (ppRb) immunoreactivity in AD neurons has previously been described $[5,6]$. In the midfrontal and temporal cortex ppRb immunoreactivity can be most prominently detected in the nucleus of the large pyramidal neurons of layers III and V, and is rarely detected in neurofibrillary tangles. Recent studies have shown that neuronal cyclooxygenase-2 (COX-2) expression in $\mathrm{AD}$ parallels the expression of cell cycle proteins in neurons [6-8]. Previously, we observed colocalization of COX-2 with $\mathrm{ppRb}$ in neurons in the temporal cortex of $\mathrm{AD}$ and control cases [6]. Increased neuronal COX-2 expression leads to increased expression of cell cycle mediators in post mitotic neurons, as shown using a transgenic mouse model with increased neuronal COX-2 expression [9].

Once activated, microglia and astrocytes are capable of producing a variety of pro-inflammatory mediators and potentially neurotoxic substances [10], of which some have been shown to potentially induce COX-2 and cell cycle protein expression in vitro [3,11-13]. It has been shown that interleukin- $1 \beta$ induces COX- 2 expression in neuronal cell models [11,12]. and conditioned medium from $\beta$ amyloid $(\mathrm{A} \beta)$ peptide stimulated microglia induces expression of cell cycle proteins in neurons followed by cell death [13]. These in vitro findings indicate that the activation of microglia may play an important role in the expression of COX-2 and cell cycle proteins in neurons. Post mortem as well as in vivo studies indicate that microglial activation already occurs at an early stage in $\mathrm{AD}$ pathology $[14,15]$. Cell cycle changes and increased neuronal COX-2 expression have also been shown to be early events in $\mathrm{AD}[1,7,16,17]$. We therefore hypothesized that neuronal expression of COX- 2 and ppRb would be associated with increased presence and activation of glial cells.

Using post mortem brain tissue we have investigated whether activation/occurrence of microglia and astrocytes in $\mathrm{AD}$ brain can be correlated with the neuronal expression of COX-2 and ppRb during AD pathogenesis. Staging of $\mathrm{AD}$ was neuropathologically evaluated according to Braak and Braak [18]. Demographic characteristics of the cases used in this study are shown in table 1 . For each case the area density of the immunoreactivity for KP1, CR3/43 and GFAP in the mid-temporal cortex was determined. KP1 (anti-CD68) is a marker for phagocytic microglia (and macrophages) and CR3/43 detects the class II antigens HLA-DP, DQ, DR and is generally used as a marker for activated microglia. GFAP (Glial Fibrillary Acidic Protein) is strongly and specifically expressed in astrocytes. Group summaries are expressed as box-plots for each Braak stage for neurofibrillary changes or amyloid deposits [18] (figure 1). All three markers show a gradual increase with increasing pathology. Correlation analysis reveals a statistically significant $(\mathrm{p}<0.05)$ positive correlation between the Braak scores for neurofibrillary changes (NF) or $A \beta$ deposits (AMY) and immunoreactiv-

Table I: Demographic characteristics of the cases used in this study. Shown are differences between groups of the cases used in this study. [PMI post-mortem interval, SD standard deviation].

\begin{tabular}{|c|c|c|c|c|c|}
\hline & \multicolumn{5}{|c|}{ Braak score for neurofibrillary changes } \\
\hline & O & I-II & III-IV & $\mathrm{V}-\mathrm{VI}$ & \\
\hline n & 5 & 16 & 10 & 9 & \\
\hline male/female & $3 / 2$ & $6 / 10$ & $0 / 10$ & $3 / 6$ & \\
\hline mean age $\pm S D$ (years) & $62 \pm 10$ & $83 \pm 8$ & $89 \pm 4$ & $76 \pm 7$ & \\
\hline \multirow[t]{3}{*}{ PMI \pm SD (hrs:min) } & $8: 00 \pm 4: 30$ & $7: 30 \pm 2: 30$ & $6: 30 \pm 2: 30$ & $5: 00 \pm 1: 30$ & \\
\hline & \multicolumn{4}{|c|}{ Braak score for amyloid deposits } & \\
\hline & O & A & B & C & total \\
\hline $\mathbf{n}$ & 7 & 6 & 11 & 16 & 40 \\
\hline male/female & $4 / 3$ & $3 / 3$ & $3 / 8$ & $2 / 14$ & $12 / 28$ \\
\hline mean age $\pm S D$ (years) & $69 \pm 12$ & $79 \pm 4$ & $85 \pm 10$ & $82 \pm 10$ & $80 \pm 11$ \\
\hline PMI \pm SD (hrs:min) & $7: 00 \pm 4: 00$ & $8: 30 \pm 3: 00$ & $7: 00 \pm 2: 30$ & $6: 00 \pm 2: 00$ & $6: 30 \pm 2: 30$ \\
\hline
\end{tabular}



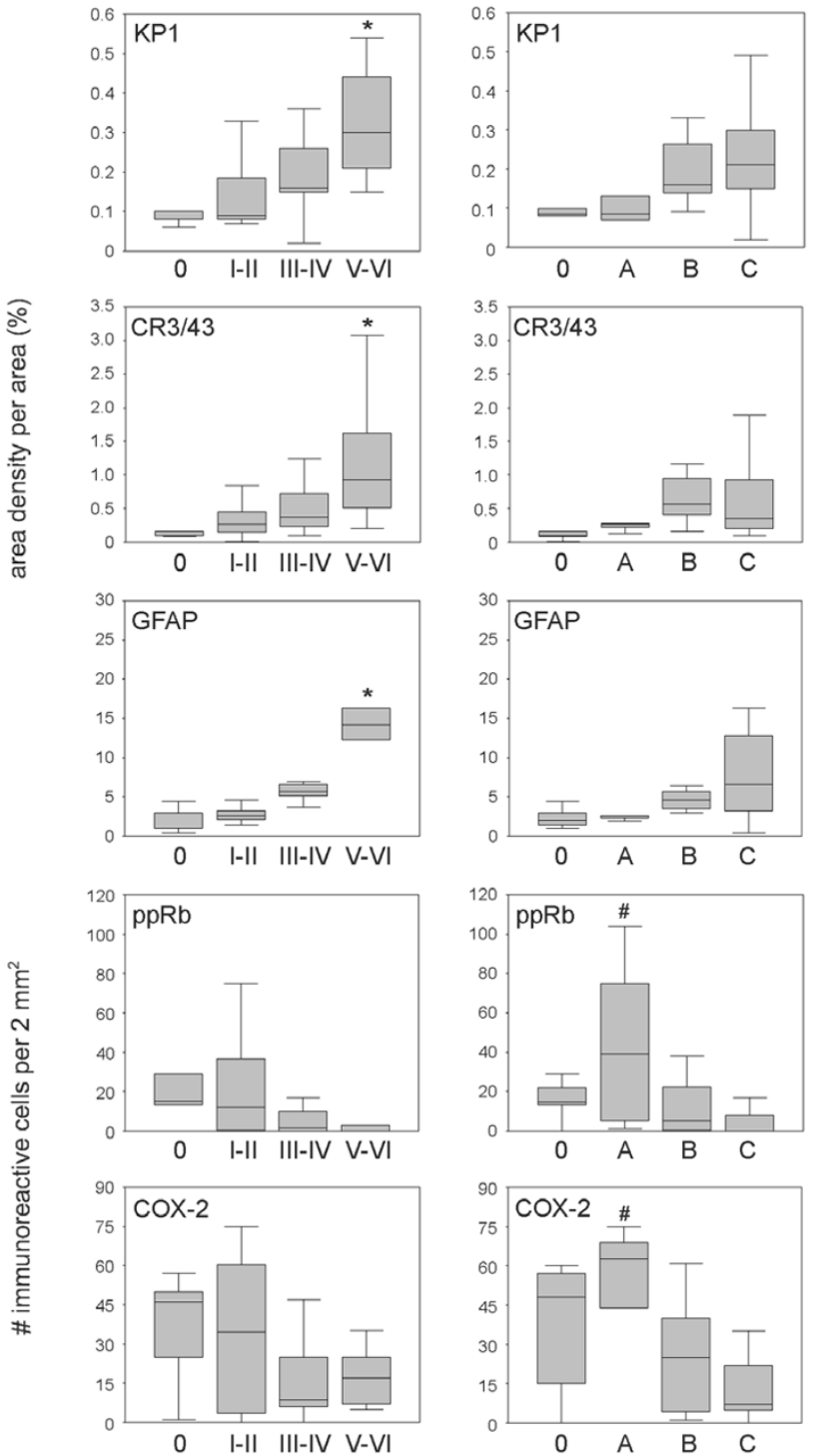

Braak stage

\section{Figure I}

Immunoreactivity scores for KPI, CR3/43, GFAP, ppRb and COX-2 in the temporal cortex of nondemented control and AD cases. Immunohistochemical stainings were performed as described previously [6]. The following primary antibodies were used: rabbit polyclonal anti-COX-2 (Cayman, Ann Arbor, MI), rabbit anti-phosphoserine pRb (pSer 795, Cell Signaling, Beverly, MA). Mouse anti-CD68 (KPI) and mouse anti-HLA-DP, DQ, DR (CR3/43) were obtained from DAKO (Heverlee, Belgium). Mouse anti-Glial Fibrillary Acidic Protein (GFAP) was obtained from Monosan (clone 6F2, Uden, The Netherlands). Morphometric investigation was aimed at determining the area density occupied by the immunoreactive glial cells in the cortical layer. The area density (\%) was quantified using Image-Pro Plus analysis software (Media Cybernetics, Silver Spring, MD). Immunoreactive neurons (COX-2 and PpRb) were counted in a total area of $2 \mathrm{~mm}^{2}$. Neurons were distinguished from non-neuronal cells by nuclear size and shape. Values of cases are grouped according to the Braak stage for neurofibrillary changes $(\mathrm{O}, \mathrm{I}-\mathrm{II}, \mathrm{III}-\mathrm{IV}, \mathrm{V}-\mathrm{VI})$ or $\mathrm{A} \beta$ deposits $(\mathrm{O}, \mathrm{A}, \mathrm{B}, \mathrm{C})$. Results are expressed as box plots. The box represents the interquartile range that contains $50 \%$ of the values. The whiskers extend from the box to the highest and lowest values. The line across the box indicates the median. Kruskall-Wallis test was used to evaluate differences between groups followed by the MannWhitney $U$ test, to test differences between pairs of groups. Correlation analysis was done using the Pearson parametric and Spearman non-parametric method. * $p<0.05$ versus Braak stage $O$. \# $p<0.05$ versus Braak stage $C$. 
ity for KP1 (NF, 0.671; AMY, 0.432), CR3/43 (NF, 0.564; AMY, 0.323), and GFAP (NF, 0.690; AMY, 0.424). A statistically significant increase was observed in Braak stage $\mathrm{V}$ VI for KP1 ( $\mathrm{p}=0.001)$, CR3/43 ( $=0.008)$, and GFAP ( $\mathrm{p}$ $<0.001$ ) compared to Braak stage 0 . Neuronal ppRb and COX-2 immunoreactivity are expressed as number of immunoreactive neurons per $2 \mathrm{~mm}^{2}$ (figure 1). A significant $(\mathrm{p}<0.05)$ negative correlation was observed between the Braak score for neurofibrillary changes and ppRb ($0.414)$ or COX-2 (-0.346), and between the Braak score for $\mathrm{A} \beta$ plaques and COX-2 (-0.537).

Although it is tempting to assume that these stages reflect the clinical changes, this study aims to show the relation between different molecular pathologically defined events. Cases with Braak stage A used in this study had either Braak stage I or II for neurofibrillary changes. In Braak stage A for amyloid low densities of amyloid plaques are only found in the temporal cortex and other parts of the isocortex [18]. Activated glial cells are mostly associated with neuritic plaques not with diffuse $A \beta$ plaques [10]. This is in agreement with our data which shows a gradual increase in microglia and astrocytes with the Braak score for neurofibrillary changes and high levels of activated glial cells in cases with Braak score B and C (figure 1).

We observed maximal neuronal ppRb and COX-2 immunoreactivity in Braak stages 0 and A. No significant difference in ppRb and COX-2 immunoreactivity was observed between the Braak stages for neurofibrillary changes. The maximal ppRb and COX-2 immunoreactivity in stage A did not significantly differ from stage O. However, we did observe a significant decrease in Braak stage $\mathrm{C}$ compared to stage A. These findings contradict previous studies that have shown increased neuronal COX-2 expression $[19,20]$ and ppRb immunoreactivity in AD cases [5]. In the present study the patients are grouped according to the Braak stage instead of being defined as control or AD. Other, previously described [17], discrepancies are most likely due to differences in pathological disease state and investigated brain area, methods of analysis, as well as technical issues. The data presented in this study are in agreement with the findings of Yermakova and O'Banion [17]. In an immunohistochemical study they found a decrease in the number of COX-2 immunoreactive neurons in advanced stages of AD. A similar trend, as shown in the present study, was observed in the hippocampus comparing the mean neuronal COX-2 immunoreactivity with the Braak score for NF. A non-significant higher mean level in Braak stage I-II was also reported [17]. The levels of neuronal COX-2 expression observed in post mortem brain tissue correlate well with recent clinical data presented by Combrinck and colleagues [21] describing, compared to control patients, higher prostaglandin E2 levels in the cerebrospinal fluid in patients with mild memory impairment, but lower in those with more advanced AD.

A significant negative correlation was observed between the area density of KP1 and the immunoreactivity for ppRb $(-0.414, \mathrm{p}=0.007)$ and COX-2 (-0.366, $\mathrm{p}=0.020)$. These data suggest no (positive) relation between neuronal expression of $\mathrm{COX}-2$ or $\mathrm{ppRb}$ and the increased glial response observed during $\mathrm{AD}$ pathology. Although suggested by in vitro studies, our evaluation of post mortem brain tissue suggests that it is very unlikely that activation of microglia or astrocytes cause neuronal expression of COX-2 and ppRb in AD. Although the involvement of activated glia in the initial upregulation of these factors seems unlikely, we cannot exclude the involvement of glia in the regulation of COX-2 or cell cycle protein expression in neurons at later stages of pathology.

COX-2 and cell cycle changes can be detected in neurons that are vulnerable for developing neurodegenerative changes that are associated with $\operatorname{AD}[6,16,22]$. This implies that COX-2 and neuronal cell cycle changes occur in the early steps of $\mathrm{AD}$ neurodegeneration. Moreover, high levels of neuronal COX-2, ppRb, cyclin D1 and cyclin $\mathrm{E}$ are found in the temporal cortex of cases which have diffuse $A \beta$ deposits while fibrillar/neuritic plaques are absent $[6,7]$. Various in vitro studies using neuronal models show that $A \beta$ peptide induces COX-2 [20] and phosphorylation of pRb $[23,24]$, which is followed by neuronal cell death. In this perspective, the current emerging data on the early role of oligomeric and protofibrilic forms of $A \beta$ in $A D$ is very interesting $[25,26]$. Whether COX-2 and cell cycle proteins are part of the molecular mechanisms involved in the response to intraneuronal accumulation of $A \beta$ and the consequent impaired synaptic function needs to be addressed in future studies.

\section{Competing interests}

The author(s) declare that they have no competing interests.

\section{Authors' contributions}

JJMH participated in the design of the study, performed the statistical analysis and prepared the manuscript. ESvH carried out the immunohistochemical analyis and quantification of the immunohistochemical data. RV has been involved in the collection of the human post mortem brain material. TA, WS, PE and AJMR participated in the design of the study and helped to draft the manuscript. All authors read and approved the final manuscript.

\section{Acknowledgements}

The authors thank the Netherlands Brain Bank for supplying the human brain tissue (coordinator Dr. R. Ravid) and Dr. W. Kamphorst for the neuropathological diagnosis of control and AD tissue. This study was sup- 
ported by the Internationale Stichting Alzheimer Onderzoek (ISAO grant 04503 to JJMH) and the European Community (ADIT programme, LSHBCT-5I 1977 to AJMR).

\section{References}

I. Nagy Z, Esiri MM, Cato AM, Smith AD: Cell cycle markers in the hippocampus in Alzheimer's disease. Acta Neuropathol (Berl) 1997, 94:6-15.

2. Arendt T, Rodel L, Gartner U, Holzer M: Expression of the cyclindependent kinase inhibitor pl 6 in Alzheimer's disease. Neuroreport 1996, 7:3047-3049.

3. Arendt T: Synaptic plasticity and cell cycle activation in neurons are alternative effector pathways: the 'Dr. Jekyll and Mr. Hyde concept' of Alzheimer's disease or the yin and yang of neuroplasticity. Prog Neurobiol 2003, 71 :83-248.

4. Sherr Cl: Cancer cell cycles. Science 1996, 274: |672-1677.

5. Jordan-Sciutto KL, Malaiyandi LM, Bowser R: Altered distribution of cell cycle transcriptional regulators during Alzheimer disease. J Neuropathol Exp Neurol 2002, 6 I:358-367.

6. Hoozemans JJ, Veerhuis R, Rozemuller AJ, Arendt T, Eikelenboom P: Neuronal COX-2 expression and phosphorylation of pRb precede $\mathbf{p} 38$ MAPK activation and neurofibrillary changes in AD temporal cortex. Neurobiol Dis 2004, I 5:492-499.

7. Hoozemans J], Bruckner MK, Rozemuller AJ, Veerhuis R, Eikelenboom P, Arendt T: Cyclin DI and cyclin E are co-localized with cyclo-oxygenase 2 (COX-2) in pyramidal neurons in Alzheimer disease temporal cortex. J Neuropathol Exp Neurol 2002, 6 I:678-688.

8. Mirjany M, Ho L, Pasinetti GM: Role of cyclooxygenase-2 in neuronal cell cycle activity and glutamate-mediated excitotoxicity. J Pharmacol Exp Ther 2002, 301:494-500.

9. Xiang Z, Ho L, Valdellon J, Borchelt D, Kelley K, Spielman L, Aisen PS, Pasinetti GM: Cyclooxygenase (COX)-2 and cell cycle activity in a transgenic mouse model of Alzheimer's disease neuropathology. Neurobiol Aging 2002, 23:327-334.

10. Akiyama H, Barger S, Barnum S, Bradt B, Bauer J, Cole GM, Cooper NR, Eikelenboom P, Emmerling M, Fiebich BL, Finch CE, Frautschy S, Griffin WS, Hampel H, Hull M, Landreth G, Lue L, Mrak R, Mackenzie IR, McGeer PL, O'Banion MK, Pachter J, Pasinetti G, Plata-Salaman C, Rogers J, Rydel R, Shen Y, Streit W, Strohmeyer R, Tooyoma I, Van Muiswinkel FL, Veerhuis R, Walker D, Webster S, Wegrzyniak B, Wenk G, Wyss-Coray T: Inflammation and Alzheimer's disease. Neurobiol Aging 2000, 2 I:383-42I.

II. Fiebich BL, Mueksch B, Boehringer M, Hull M: Interleukin-Ibeta induces cyclooxygenase-2 and prostaglandin $E(2)$ synthesis in human neuroblastoma cells: involvement of p38 mitogenactivated protein kinase and nuclear factor-kappaB. J Neurochem 2000, 75:2020-2028.

12. Hoozemans JJ, Veerhuis R, Janssen I, Rozemuller AJ, Eikelenboom P. Interleukin- I beta induced cyclooxygenase 2 expression and prostaglandin E2 secretion by human neuroblastoma cells: implications for Alzheimer's disease. Exp Gerontol 2001, 36:559-570.

13. Wu Q, Combs C, Cannady SB, Geldmacher DS, Herrup K: Betaamyloid activated microglia induce cell cycling and cell death in cultured cortical neurons. Neurobiol Aging 2000, 2 I:797-806.

14. Arends YM, Duyckaerts C, Rozemuller JM, Eikelenboom P, Hauw J]: Microglia, amyloid and dementia in alzheimer disease. A correlative study. Neurobiol Aging 2000, 21 :39-47.

15. Cagnin A, Brooks DJ, Kennedy AM, Gunn RN, Myers R, Turkheimer $\mathrm{FE}$, Jones T, Banati RB: In-vivo measurement of activated microglia in dementia. Lancet 200I, 358:46I-467.

16. Busser J, Geldmacher DS, Herrup K: Ectopic cell cycle proteins predict the sites of neuronal cell death in Alzheimer's disease brain. I Neurosci 1998, I 8:2801-2807.

17. Yermakova AV, O'Banion MK: Downregulation of neuronal cyclooxygenase- 2 expression in end stage Alzheimer's disease. Neurobiol Aging 200I, 22:823-836.

18. Braak H, Braak E: Neuropathological stageing of Alzheimerrelated changes. Acta Neuropathol (Berl) I991, 82:239-259.

19. Oka A, Takashima S: Induction of cyclo-oxygenase 2 in brains of patients with Down's syndrome and dementia of Alzheimer type: specific localization in affected neurones and axons. Neuroreport 1997, 8: I 16I-II64.
20. Pasinetti GM, Aisen PS: Cyclooxygenase-2 expression is increased in frontal cortex of Alzheimer's disease brain. Neuroscience 1998, 87:319-324.

21. Combrinck M, Williams J, De Berardinis MA, Warden D, Puopolo M, Smith AD, Minghetti L: Levels of CSF prostaglandin E2, cognitive decline and survival in Alzheimer's disease. J Neurol Neurosurg Psychiatry 2005.

22. Yang Y, Mufson EJ, Herrup K: Neuronal cell death is preceded by cell cycle events at all stages of Alzheimer's disease. J Neurosci 2003, 23:2557-2563.

23. Giovanni A, Wirtz-Brugger F, Keramaris E, Slack R, Park DS: Involvement of cell cycle elements, cyclin-dependent kinases, $p R \mathbf{b}$, and E2F $x$ DP, in B-amyloid-induced neuronal death. J Biol Chem 1999, 274:19011-19016.

24. Copani A, Condorelli F, Caruso A, Vancheri C, Sala A, Giuffrida Stella AM, Canonico PL, Nicoletti F, Sortino MA: Mitotic signaling by beta-amyloid causes neuronal death. Faseb J 1999 , I 3:2225-2234.

25. Klyubin I, Walsh DM, Lemere CA, Cullen WK, Shankar GM, Betts V, Spooner ET, Jiang L, Anwyl R, Selkoe DJ, Rowan MJ: Amyloid beta protein immunotherapy neutralizes Abeta oligomers that disrupt synaptic plasticity in vivo. Nat Med 2005, I I:556-56 I.

26. Gouras GK, Almeida CG, Takahashi $\mathrm{RH}$ : Intraneuronal Abeta accumulation and origin of plaques in Alzheimer's disease. Neurobiol Aging 2005, 26: $1235-1244$.
Publish with Bio Med Central and every scientist can read your work free of charge

"BioMed Central will be the most significant development for disseminating the results of biomedical research in our lifetime. "

Sir Paul Nurse, Cancer Research UK

Your research papers will be:

- available free of charge to the entire biomedical community

- peer reviewed and published immediately upon acceptance

- cited in PubMed and archived on PubMed Central

- yours - you keep the copyright

Submit your manuscript here:

http://www.biomedcentral.com/info/publishing_adv.asp
BioMedcentral 